\title{
Two Distinct Soil Disinfestations Differently Modify the Bacterial Communities in a Tomato Field
}

\author{
Masaru Nakayasu ${ }^{1,+} \mathbb{D}$, Kyoko Ikeda $^{2,+} \mathbb{D}$, Shinichi Yamazaki ${ }^{3}$, Yuichi Aoki ${ }^{3} \mathbb{D}$, Kazufumi Yazaki $^{1}$, \\ Haruhiko Washida $^{2}(\mathbb{D})$ and Akifumi Sugiyama ${ }^{1, *}$
}

Citation: Nakayasu, M.; Ikeda, K.; Yamazaki, S.; Aoki, Y.; Yazaki, K.; Washida, H.; Sugiyama, A. Two Distinct Soil Disinfestations Differently Modify the Bacterial Communities in a Tomato Field. Agronomy 2021, 11, 1375. https:/ / doi.org/10.3390/agronomy11071375

Academic Editors: José

María García-Mina, Jörg Gerke and Salvatore Davino

Received: 14 May 2021

Accepted: 2 July 2021

Published: 7 July 2021

Publisher's Note: MDPI stays neutral with regard to jurisdictional claims in published maps and institutional affiliations.

Copyright: (C) 2021 by the authors. Licensee MDPI, Basel, Switzerland. This article is an open access article distributed under the terms and conditions of the Creative Commons Attribution (CC BY) license (https:/ / creativecommons.org/licenses/by/ $4.0 /)$.
1 Research Institute for Sustainable Humanosphere, Kyoto University, Gokasho, Uji 611-0011, Japan; masaru_nakayasu@rish.kyoto-u.ac.jp (M.N.); yazaki@rish.kyoto-u.ac.jp (K.Y.)

2 Organic Nico Co., Ltd., Oharanohaigata, Nishikyo-ku, Kyoto 610-1132, Japan; ikeda.k@organic-nico.com (K.I.); washida.h@organic-nico.com (H.W.)

3 Tohoku Medical Megabank Organization, Tohoku University, Sendai 980-8573, Japan; yamazaki.shinichi@megabank.tohoku.ac.jp (S.Y.); aoki@megabank.tohoku.ac.jp (Y.A.)

* Correspondence: akifumi_sugiyama@rish.kyoto-u.ac.jp; Tel.: +81-774-38-3617

+ These authors contributed equally to this study.

\begin{abstract}
Reductive soil disinfestation (RSD) and soil solarization (SS) were evaluated based on environmental factors, microbiome, and suppression of Fusarium oxysporum in a tomato field soil. Soil environmental factors (moisture content, electric conductivity, $\mathrm{pH}$, and redox potential (RP)) were measured during soil disinfestations. All factors were more strongly influenced by RSD than SS. 16S rRNA amplicon sequencing of RSD- and SS-treated soils was performed. The bacterial communities were taxonomically and functionally distinct depending on treatment methods and periods and significantly correlated with $\mathrm{pH}$ and RP. Fifty-four pathways predicted by PICRUSt2 (third level in MetaCyc hierarchy) were significantly different between RSD and SS. Quantitative polymerase chain reaction demonstrated that both treatments equally suppressed F. oxysporum. The growth and yield of tomato cultivated after treatments were similar between RSD and SS. RSD and SS shaped different soil bacterial communities, although the effects on pathogen suppression and tomato plant growth were comparable between treatments. The existence of pathogen-suppressive microbes, other than Clostridia previously reported to have an effect, was suggested. Comparison between RSD and SS provides new aspects of unknown disinfestation patterns and the usefulness of SS as an alternative to RSD.
\end{abstract}

Keywords: bacterial communities; Fusarium oxysporum; reductive soil infestation; soil solarization; tomato

\section{Introduction}

Increasing food production is one of the most important challenges to meet the global population growth of the 21st century. Chemical fertilizers and synthetic pesticides have been used for stable crop growth, pest control, and yield increase worldwide [1]. In conventional agriculture, pest control depends on chemical pesticides; for example, soil fumigants, such as chloropicrin, metam-sodium, and dazomet, are used for broadspectrum pest control [2-4]. However, conventional agricultural systems simultaneously degrade the global environment (e.g., land, water, biodiversity, and climate) and consume a tremendous amount of natural resources [5]. Organic farming, the management system limiting chemical fertilizers and synthetic pesticides, is a promising solution for these negative impacts. A meta-analysis to compare organic and conventional farming showed that organic farming has positive environmental impacts per area unit, but not necessarily per product unit [6]. Nevertheless, organic farming has been shown to improve soil fertility and reduce global warming potential [7]. Although organic farming is considered more environmentally friendly than conventional farming, it produces lower crop yields than 
conventional farming [8]. However, recent studies propose that organic farming can provide adequate food to the world population in 2050 if consumption of food waste and animal products is reduced $[9,10]$ and that a complete shift to organic farming would be difficult because of global nitrogen deficiency [11]. The latter study also suggests that organic farming can serve to provide food for the world population more sustainably and fairly. As soilborne diseases cause severe damage in crops, the appropriate disease management is important, especially in organic farming in which the use of chemical pesticides is restricted. To date, many studies compared crop diseases in organic and conventional farming, indicating that root diseases are generally less serious but some foliar diseases can be a problem in organic agriculture [12]. It is difficult to prevent plant disease and insect damage in organic farming. Indeed, organically cultivated lands account for only $1.4 \%$ of the global agricultural lands, although organic farming is practiced in 181 countries [13]. Therefore, the establishment of the organic farming method is required for its prevalence.

The environmentally friendly managements are practiced, for example, by soil disinfestation, resistant cultivars and grafting, biopesticides, and disease-suppressive soils [14]. Reductive soil disinfestation (RSD) was developed to control pathogens without synthetic pesticides $[15,16]$. This method causes reductive soil conditions by adding easily decomposable organic matter for microbial activation, irrigating the expulsion of soil air, and covering the soil surface with plastic film to block the inflow of oxygen from the atmosphere for several weeks. A meta-analysis based on many RSD studies showed that it effectively suppresses pathogens, nematodes, and weeds and tends to promote crop productivity [17]. Reductive conditions, high temperature, release of metal ions, and generation of organic acids, toxic compounds, and antipathogenic enzymes are thought to cause pathogen suppression by RSD $[18,19]$. In addition, indigenous soil microorganisms are essential for pathogen suppression [20]. Both biotic and abiotic factors appear to contribute to this suppression in a complicated manner, although it is not completely understood.

In organic farming with and without RSD treatment, the application of organic matter increases microbial abundance and activity and distinctively affects microbial communities compared to those of mineral fertilization [21-23]. Because plant growth and defense depend on microbial communities in rhizosphere soils [24], the characterization of their influence in organic farming is important for establishing sustainable agriculture. Many previous studies have shown that RSD modulates bacterial community and increases the bacterial phylum Firmicutes in treated soils, especially Bacilli and an obligate anaerobe Clostridia, and that the latter can produce $\beta$-1,3-glucanase and chitosanase to kill the Fusarium pathogens [25-31]. Lee et al. [32] reported that some operational taxonomic units of Clostridia and Bacilli, but not the whole microbial communities, were negatively correlated with the density of a tomato pathogen Fusarium oxysporum f. sp. lycopersici (FOL). Thus, specific microbes are potentially responsible for pathogen suppression. Still, it remains unknown how these microbes are enriched in microbial communities and how abiotic factors are correlated with the communities during RSD treatment.

Soil solarization (SS) is another soil disinfestation technique without synthetic pesticides under the heat generated by covering wet soil with plastic film and exposing it to sunlight. SS affects the physical, chemical, and biological soil environment and then causes the elimination of pathogens and weeds and improvement to plant growth [33]. Recently, Ichihashi et al. [34] reported that SS modulated distinct bacterial communities in the rhizosphere soil and that SS-induced organic nitrogen increased crop yield. Disease-suppressive soil allows the plant to protect from pathogens as a result of antagonistic and competitive activities of the microbiota, and its effect is enhanced by treatment with organic matter, compost, and agronomic practices [35-37]. Therefore, it is important to assess the effects of RSD and SS on soil microbiota which affects plant growth and health. RSD and SS are similar soil disinfestation methods without chemical pesticides, but the differential effects on soil microbiota remain unknown. This study compared the RSD and SS soil disinfestation methods based on soil environmental factors and tomato plants cultivated 
after treatments and yield. Both practices had similar effects on the disinfestation of $F$. oxysporum, although they shaped different soil bacterial communities.

\section{Materials and Methods}

\subsection{Soil Disinfestations and Sampling}

Field experiments were performed in a plastic multispan greenhouse $(4 \mathrm{~m} \times 24 \mathrm{~m} \times 6 \mathrm{~m})$ located in Kyoto Prefecture, Japan $\left(35.0^{\circ} \mathrm{N}, 135.4^{\circ} \mathrm{E}\right)$, where the type of soil was clay accumulation red yellow. Three plots were designed for RSD (Plots 1-3) and SS (Plots 4-6) treatments (a total of six plots; size, $1.2 \mathrm{~m} \times 20 \mathrm{~m}$ per plot). Both treatments were started on 6 August 2019. Wheat bran $(2 \% \mathrm{~N}$ and $40 \% \mathrm{C}$, estimated available nitrogen and carbon supply; Tamagoya-Shoten, Ibaraki, Japan) was applied at $1.2 \mathrm{~kg} \mathrm{~m}^{-2}$ to RSD, and BLOF compost $(0.9 \% \mathrm{~N}$ and $20.7 \% \mathrm{C}$, estimated available nitrogen and carbon supply; Japan Bio Farm Ltd., Nagano, Japan) was applied at $2.5 \mathrm{~kg} \mathrm{~m}^{-2}$ to SS. The initial (estimated) volumetric moisture content (MC) was adjusted to about $40 \%$ for RSD and about $30 \%$ for SS by irrigation, and the soil surface was covered with plastic films. The temperature in the greenhouse was controlled not to exceed $50{ }^{\circ} \mathrm{C}$ in the daytime by the environmental controller and the other temperature was entrusted. Changes in air temperatures were shown in Supplemental Figure S1 and the mean temperature during this period was $29.8^{\circ} \mathrm{C}$. The films were removed on 27 August 2019, and the temperature was changed to ambient temperature (mean of $30^{\circ} \mathrm{C}$ ). Soils were sampled on 6 August 2019 before the start, 13, 16, 20, 24, 27, and 30 August and 3, 6, 10, and 13 September 2019, during the treatment period, and 13 November 2019 and 22 January 2020, during the tomato cultivation period. Soils were collected from three different points with a core size of $17 \mathrm{~mm}$ in diameter at a depth of $0-15 \mathrm{~cm}$ from the surface in each plot for one sample. These soils were used for the measurement of environmental factors and DNA extraction.

\subsection{Environmental Factor Measurement}

The soils sampled during the treatment period were dried at $60^{\circ} \mathrm{C}$ for $48 \mathrm{~h}$. MC, electric conductivity (EC), and $\mathrm{pH}$ were measured. $\mathrm{MC}$ was calculated by subtracting the weight of the dry soil from the weight of the moist soil divided by the weight of the dry soil. A 1:5 (w/v) ratio of dried soil and water was used for measuring EC and $\mathrm{pH}$ by LAQUAtwin EC-11 conductivity meter and LAQUAtwin $\mathrm{pH}-11 \mathrm{pH}$ meter, respectively (HORIBA Ltd., Kyoto, Japan). Besides, redox potential (RP) was continuously monitored by an FV-702 RP sensor (Fujiwara Seisakusho Ltd., Tokyo, Japan).

\subsection{DNA Extraction and $16 S$ rRNA Amplicon Sequencing}

DNA was extracted from the soils sampled on 6, 13, 20, and 27 August, 3 and 10 September, and 13 November 2019 and 22 January 2020, using the DNeasy PowerSoil Kit (QIAGEN K.K., Tokyo, Japan). The DNA concentration was measured by a Qubit dsDNA HS Assay Kit and Qubit 2.0 Fluorometer (Thermo Fisher Scientific, Waltham, MA, USA). Polymerase chain reaction (PCR) amplification of the V4 region of bacterial 16S rRNA was performed using KOD FX Neo (TOYOBO, Osaka, Japan) with the following primer set: 515F (5'-ACACTCTTTCCCTACACGACGCTCTTCCGATCTGTGCCAGCMGCCGCGGTAA-3') and 806R (5'-GTGACTGGAGTTCAGACGTGTGCTCTTCCGATCTGGACTACHVGGGTW TCTAAT- $3^{\prime}$ ) in technical triplicate. PCR was conducted according to the following program: $94{ }^{\circ} \mathrm{C}$ for $2 \mathrm{~min}$ and $20 \mathrm{cycles}$ of $98^{\circ} \mathrm{C}$ for $10 \mathrm{~s}, 50^{\circ} \mathrm{C}$ for $30 \mathrm{~s}$, and $68^{\circ} \mathrm{C}$ for $30 \mathrm{~s}$. Purification of the PCR products was carried out using AMPure XP (Beckman Coulter, Danvers, MA, USA), and the purified DNA was used as a template for PCR amplification for MiSeq (Illumina, San Diego, CA, USA) adapter attachment. PCR amplification was performed using KOD FX Neo with primers provided by FASMAC Co., Ltd. (Kanagawa, Japan) in technical duplicate. PCR was conducted according to the following program: $94^{\circ} \mathrm{C}$ for $2 \mathrm{~min}$ and 10 cycles of $98^{\circ} \mathrm{C}$ for $10 \mathrm{~s}, 59^{\circ} \mathrm{C}$ for $30 \mathrm{~s}$, and $68^{\circ} \mathrm{C}$ for $30 \mathrm{~s}$. The PCR products were purified as described above. Equal amounts of DNA were mixed and applied for 
$2 \times 250$ bp paired-end sequencing using MiSeq in FASMAC. The acquired sequence data has been registered in the DNA Data Bank of Japan Sequence Read Archive (DRA012344).

\subsection{Microbiome Data Analysis}

16S rRNA amplicon sequence data were analyzed using the QIIME2 environment version 2019.7 [38]. The raw sequences were processed using the q2-dada2 plugin in QIIME2 to trim the bases other than the 21st to 200th of all paired reads and construct error-corrected amplicon sequence variants (ASVs) from the trimmed reads [39]. The taxonomic assignment of ASVs was performed using the naïve Bayes classifier pretrained on the Silva $16 \mathrm{~S}$ rRNA database release 132 [40,41]. The obtained ASV sequences were aligned using MAFFT [42]. Phylogenetic trees were constructed using FastTree2 [43]. The core-metrics-phylogenetic pipeline in the q2-diversity plugin within QIIME2 was used to calculate the $\alpha$ - and $\beta$-diversity indices of the sampled soils with a subsampled ASV dataset with 19,000 sequences per sample. Bacterial metagenome functional profiles were predicted from the obtained ASV sequences and ASV profiles using the q2-picrust2 plugin [44] with the MetaCyc database of metabolic pathways and enzymes [45]. The predicted pathways by PICRUSt2 were grouped into parent classes based on the MetaCyc pathway hierarchy version 23.5 (released on December 18, 2019; Supplemental Table S1) and used for subsequent analysis.

\subsection{Quantification of F. oxysporum in Soils}

DNA from the soils sampled on 6, 13, 20, and 27 August and 3 and 10 September 2019, were used for real-time PCR to quantify F. oxysporum in soils as templates. PCR was performed using KOD FX Neo with the following primer set: CLOX1 (5'CAGCAAAGCATCAGACCACTATAACTC- $\left.{ }^{\prime}\right)$ and CLOX2 (5'-CTTGTCAGTAACTGGAC GTTGGTACT-3') [46]. The PCR program was conducted as follows: $98^{\circ} \mathrm{C}$ for $2 \mathrm{~min}$ and 50 cycles of $98^{\circ} \mathrm{C}$ for $10 \mathrm{~s}, 60^{\circ} \mathrm{C}$ for $10 \mathrm{~s}$, and $68^{\circ} \mathrm{C}$ for $30 \mathrm{~s}$, followed by ramping up from $65^{\circ} \mathrm{C}$ to $95^{\circ} \mathrm{C}$ at $0.1^{\circ} \mathrm{C} \mathrm{s}^{-1}$. The absolute abundance of $F$. oxysporum was estimated using a calibration curve constructed using a dilution series of plasmids with cloned fragments of the specific gene.

\subsection{Tomato Cultivation and Evaluation of the Growth and Yield}

Cherry tomato (Solanum lycopersicum cv. Benisuzume; Institute for Horticultural Plant Breeding, Chiba, Japan) was cultivated after soil disinfestations. The seeds were sown in pots, and the seedlings were grown at the greenhouse for about 50 days. They were planted into the field on 23 September 2019, after disinfestations and grown with two leaders in 1.7 plants $\mathrm{m}^{-2}$. Plant growth was measured on 16 and 30 October and 13 and 27 November 2019. The length of the main stem was defined as its distance from the shoot apex to the soil surface position. The perimeter of the main stem was measured at 15 to $20 \mathrm{~cm}$ from the shoot apex. The leaf area was defined as the average of the products of width and length of the first upper and lower expanded leaves at $50 \mathrm{~cm}$ from the shoot apex of the main stem. The length of the internode was defined as the average of internode lengths from the first upper inflorescence with flowers of the main stem to the first upper and lower inflorescences. All items were measured in five plants per plot. Ripe fruits from more than 100 plants for each treatment were harvested and weighed to determine the fruit yield per unit area.

\subsection{Statistical Analysis}

The Welch's $t$-test was carried out using the t.test function of R package "stats." Tukey's test was performed using TukeyHSD function of R package "multcomp." Hierarchical clustering was performed using the complete linkage method with the hclust function in the R package "stats." Permutational multivariate analysis of variance (PERMANOVA) was performed with the adonis function in the R package "vegan" [47]. Correlation analysis between soil bacterial communities and soil properties was performed by the Mantel test 
using the weighted UniFrac (WUF) distance matrix and the Euclidian distance matrix of environmental factors in Plots 2 and 5. The R software package "vegan" was used with 10,000 permutations $\left({ }^{*} p<0.05 ;{ }^{* *} p<0.01\right)$. ANOVA-like differential expression (ALDEx2) analysis $[48,49]$ was performed to detect differentially abundant taxa at the class level and pathways predicted by PICRUSt 2 between RSD and SS with the R software package "ALDEx2" [false discovery rate (FDR) $<0.01$, Welch's $t$-test corrected by the BenjaminiHochberg method]. Low abundant taxa (mean relative abundance of $<0.1 \%$ ) were filtered out for ALDEx2 analysis.

\section{Results}

\subsection{Fluctuation of Environmental Factors during Soil Disinfestations}

To assess the soil disinfestation methods without chemical fertilizers and pesticides, the effects of RSD and SS in a cherry tomato greenhouse were compared. Both treatments were initiated by adding organic substrates and water and covering them with plastic films. Four parameters (i.e., MC, EC, pH, and RP) were monitored for 6 weeks. MC reached about $40 \%$ and $30 \%$ after the addition of water in RSD and SS, respectively, which were then decreased after 4 weeks in both conditions. MC in RSD remained continuously higher than that in SS during the test period (Figure 1A). In both conditions, EC decreased to $0.2 \mathrm{mS} \mathrm{cm}^{-1}$ for 1 week after initiation and returned to the initial levels $\left(0.5-0.6 \mathrm{mS} \mathrm{cm}^{-1}\right)$ after 5 weeks. EC in RSD was generally lower than that in SS (Figure 1B). pH increased from 6.4 to 7.4 in 3 weeks and then decreased to 6.6 in RSD; in SS, it increased from 6.4 to 7.2 in 1 week, maintained for 18 days, and then decreased to 6.9 (Figure 1C). Soil anaerobicity is described as follows: aerobic $(\mathrm{RP}>+300 \mathrm{mV})$ and anaerobic [moderately reductive $(+300$ to $0 \mathrm{mV})$, reductive $(0$ to $-200 \mathrm{mV})$, and highly reductive $(<-200 \mathrm{mV})]$ [50]. $\mathrm{RP}$ decreased to $-200 \mathrm{mV}$ after 10 days in RSD, maintained for 3 weeks, and then rapidly returned to the levels at the start (about $+600 \mathrm{mV}$ ); in SS, it decreased to $+250 \mathrm{mV}$ for 1 week, maintained for 2 weeks, and then returned to the levels at the start 3 weeks later (Figure 1D). Based on this observation, RSD and SS formed highly and moderately reduced conditions, respectively. The measurement of soil parameters revealed that RSD and SS caused different influences on the soil environmental factors.

\subsection{Changes in Bacterial Communities by Soil Disinfestations}

To evaluate the influence of RSD and SS on bacterial communities, a 16S rRNA amplicon sequence of soils during treatments was conducted. Both weighted and unweighted UniFrac (WUF and UUF)-based principal coordinate analysis (PCoA) showed a variation of the bacterial communities depending on the treatment methods and periods (PERMANOVA, $p=0.001$; Figure 2).

The differentially abundant test was performed using ALDEx2 analysis, and nine bacterial taxa at the class level were significantly different between RSD and SS (FDR $<0.01$; Supplemental Table S2). Three classes, such as Bacilli and Clostridia of Firmicutes and Deltaproteobacteria of Proteobacteria, were more abundant in RSD than in SS, and six classes, such as Acidimicrobiia of Actinobacteria, Chloroflexia and Gitt-GS-136 of Chloroflexi, Gemmatimonadetes and S0134 terrestrial group of Gemmatimonadetes, and Verrucomicrobiae of Verrucomicrobia, were more abundant in SS than in RSD (Supplemental Figure S2 and Table S2). The Mantel test was used to assess the relationships between soil bacterial communities and environmental factors. It showed that soil RP and $\mathrm{pH}$ were significantly correlated with the bacterial communities $(p<0.05$; Figure 3$)$. These results suggested that the difference of changes in bacterial communities depends on the soil disinfestation methods and that fluctuation of environmental factors affects the communities. 
A

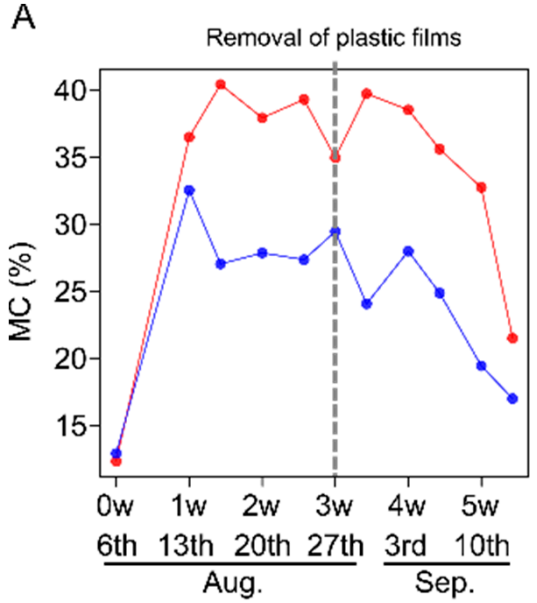

C

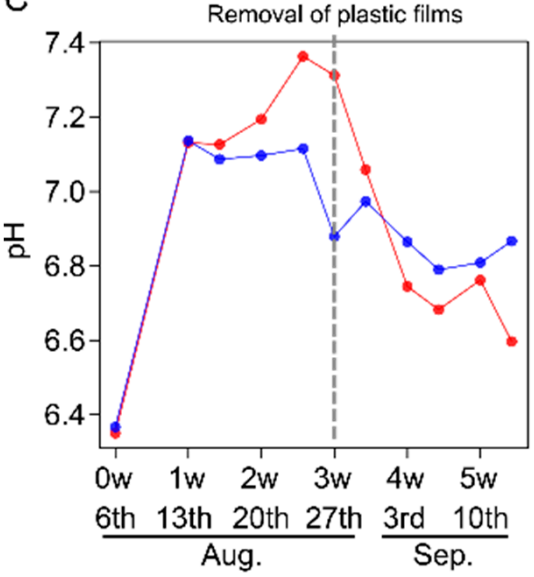

B

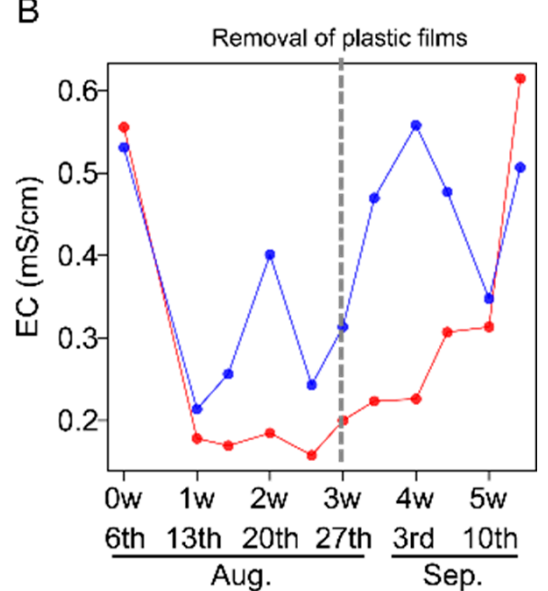

D

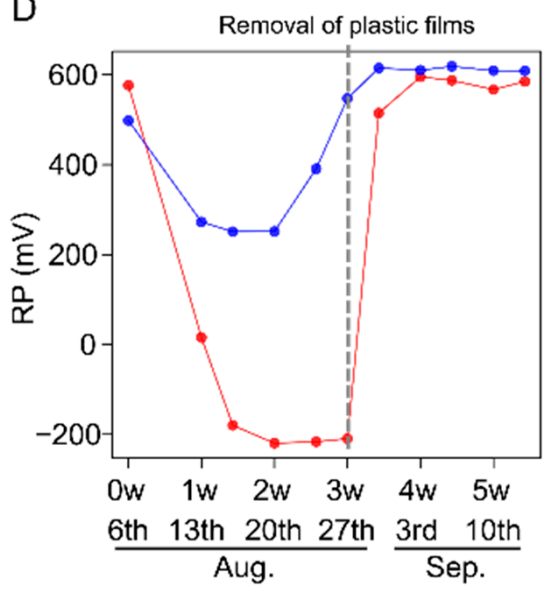

$$
\text { RSD } \quad \text { SS }
$$

Figure 1. Fluctuation of environmental parameters in soil under reductive soil disinfestation (RSD) and soil solarization (SS). Values are the average of: (A) moisture content (MC) $(n=3)$, (B) electric conductivity (EC) $(n=3)$, and (C) $\mathrm{pH}(n=3)$, and (D) the daily average of redox potential (RP) measured every hour on 6, 13, 16, 20, 24, 27, and 30 August and 3, 6, 10, and 13 September 2019. Red denotes RSD, whereas blue denotes SS.
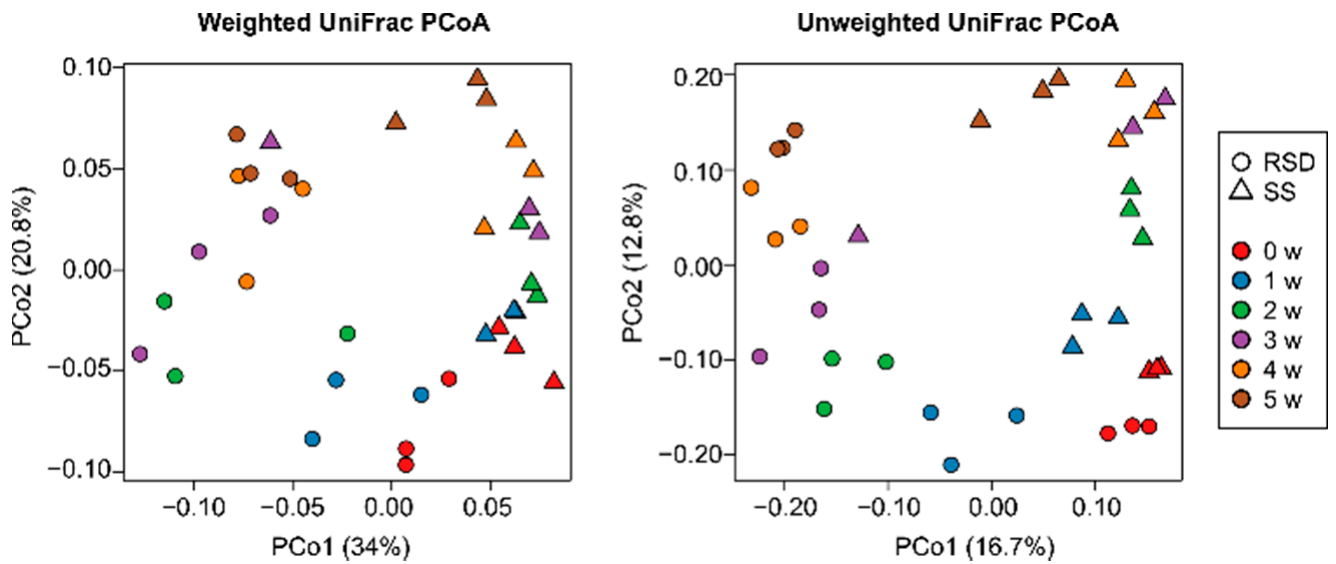

Figure 2. Weighted and Unweighted UniFrac-based principal coordinate analysis (PCOA) of the soil bacterial communities under $(\bigcirc)$ reductive soil disinfestation (RSD) and $(\triangle)$ soil solarization (SS). Red, blue, green, purple, yellow, and brown denotes $0-5 \mathrm{w}$ : treatment period for 0 to 5 weeks. 


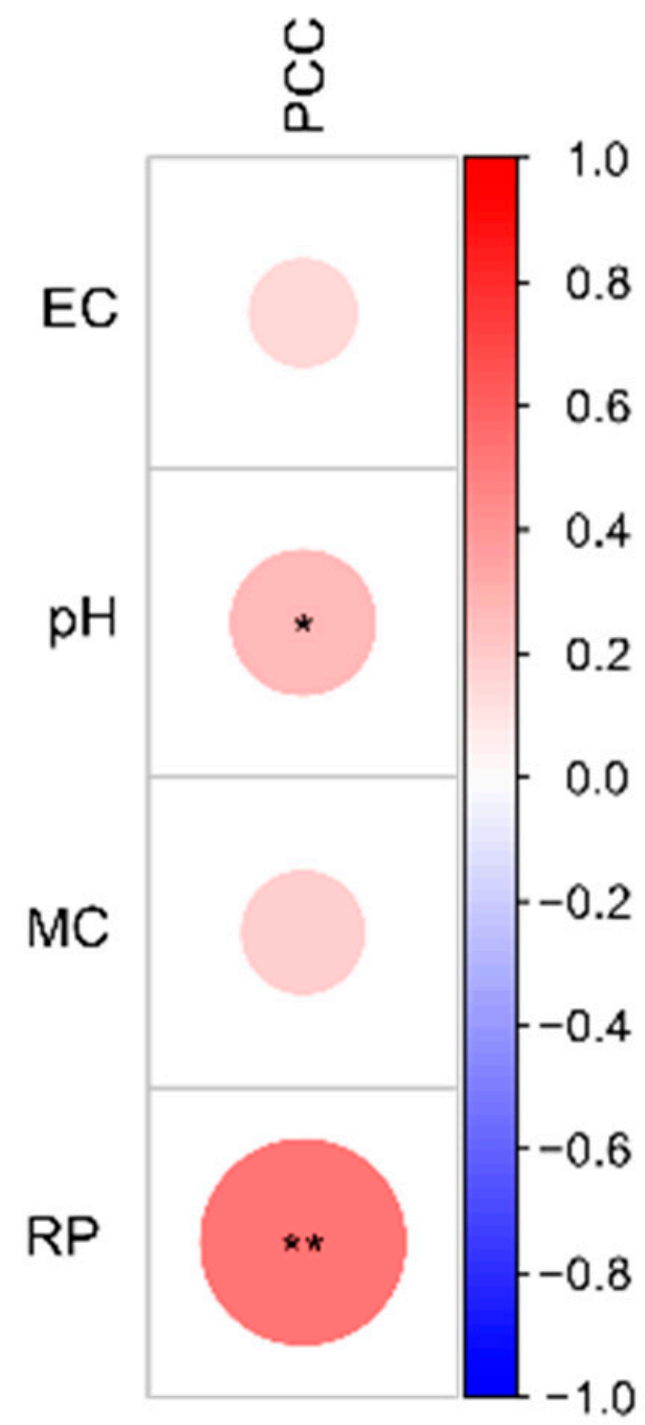

Figure 3. Correlation between soil properties and bacterial communities by the Mantel test. The scale bar indicates the Pearson correlation coefficient (PCC). Blue denotes -1 , whereas red denotes 1 . Asterisks indicate significant correlation $\left({ }^{*} p<0.05\right.$; $\left.{ }^{* *} p<0.01\right)$. EC-electric conductivity; MCmoisture content; $\mathrm{RP}$-redox potential.

\subsection{Changes in Bacterial Pathway Composition by Soil Disinfestations}

The predicted pathway composition of the bacterial metagenomes in the disinfested soils was inferred with a 16S rRNA gene sequence using the PICRUSt2 pipeline developed from PICRUSt1 to predict the functional potential of a bacterial community [44,51]. By PICRUSt2, 445 metabolic pathways were predicted for the data, and for understanding with simplicity, these pathways were grouped into parent classes based on the MetaCyc pathway hierarchy (Supplemental Table S1). Top-level (eight categories) and third level (176 categories) in the class hierarchy were used for subsequent analysis. Principal component analysis (PCA) of the functional profiles at third and eighth levels (most divided) showed a difference in the pathway compositions depending on the methods and periods of disinfestations by the first and second axes, respectively (Figure 4; Supplemental Figure S3). 
Based on functional categories at level 1 of the MetaCyc pathway, the function "Biosynthesis" accounted for about 70\%, and "Degradation/Utilization/Assimilation" and "Generation of Precursor Metabolite and Energy" accounted for about 15\% (Figure 5A). ALDEx2 analysis showed that 54 categories at level 3 of the MetaCyc pathway were significantly different between RSD and SS (FDR $<0.01$; Supplemental Table S3). Focusing on periods when environmental factors were especially different between RSD and SS (Figure 1), three categories belonging to "Degradation/Utilization/Assimilation" peaked at 2 weeks later in RSD, whereas the other eight categories peaked at 1 to 3 weeks later in SS (Figure 5B). Intriguingly, the category "Siderophore Biosynthesis" belonging to "Biosynthesis" was enriched in SS, particularly in soils 2 weeks later (Figure 5B). These results implied that the potential of siderophore production is higher in SS than in RSD.

PICRUSt2 Metabolic pathways Third level in MetaCyc hierarchy, PCA

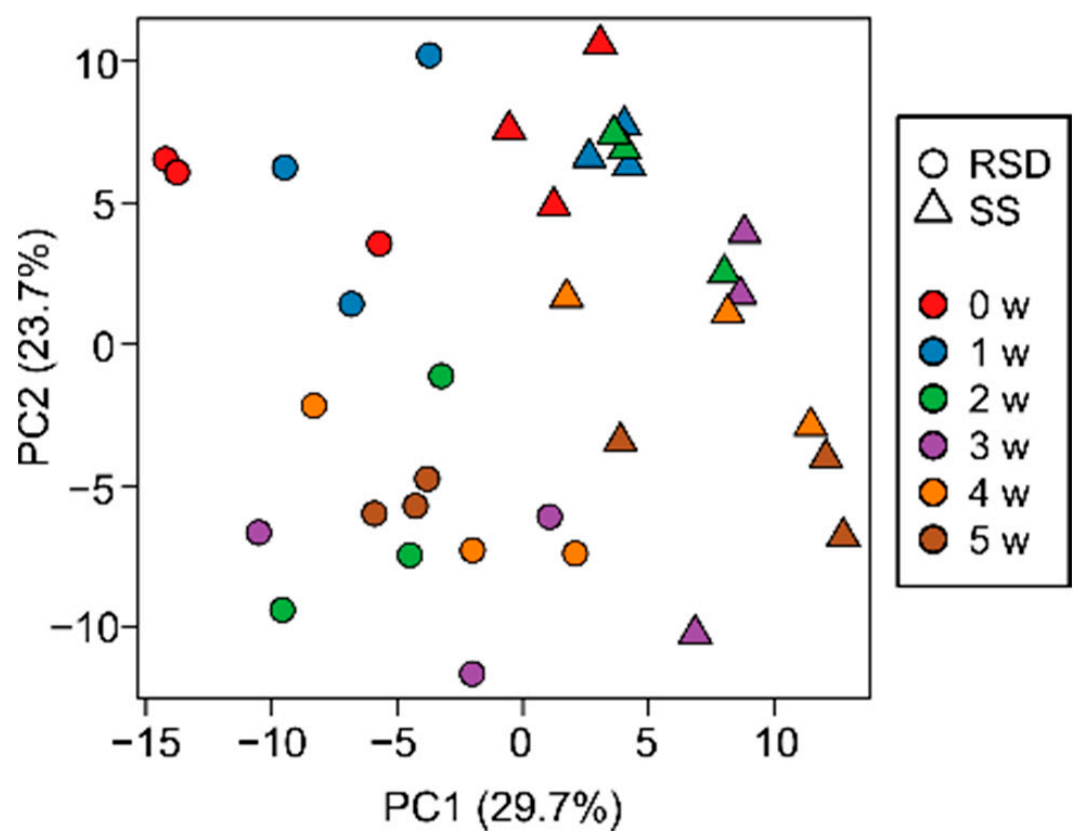

Figure 4. Principal component analysis (PCA) of the pathway composition (third level in MetaCyc hierarchy) predicted by PICRUSt2 in the soil bacterial metagenomes under $(\bigcirc)$ reductive soil disinfestation (RSD) and $(\triangle$ ) soil solarization (SS). Red, blue, green, purple, yellow, and brown denotes $0-5 \mathrm{w}$ : treatment period for 0 to 5 weeks.

\subsection{Difference of F. oxysporum Density between Two Soil Disinfestations}

To compare the effects of disinfestation methods on plant pathogens, a tomato pathogen F. oxysporum was quantified with PCR during RSD and SS treatments. F. oxysporum decreased over time in both RSD and SS. It was reduced to $6.8 \%$ of the initial amount in RSD and was below the limit of quantification in SS 5 weeks later (Figure 6). There is no significant difference between RSD and SS on the abundance of F. oxysporum, although these practices differentially affect the soil environmental factors and soil bacterial communities. 
A

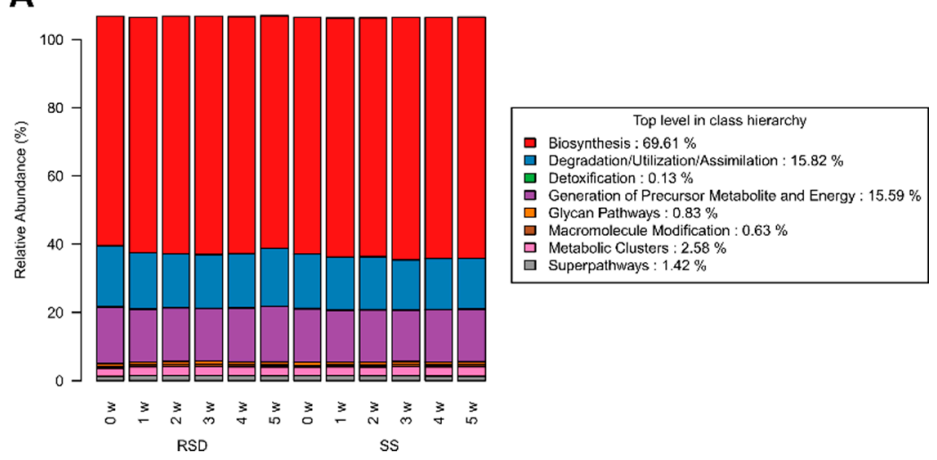

B

Differential abundant pathways

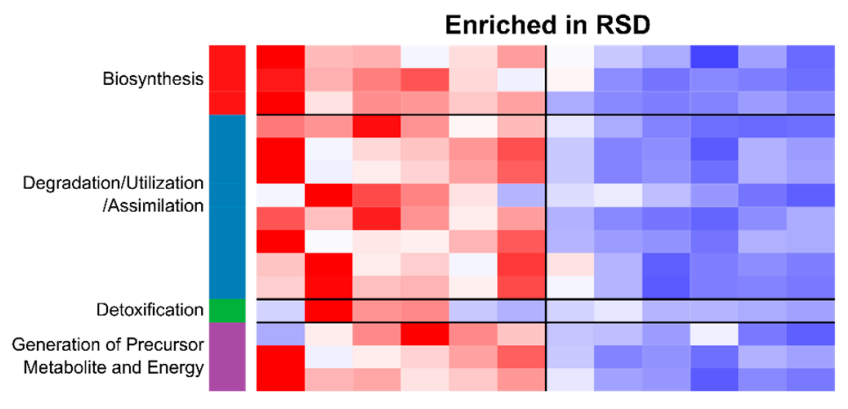

Butanediol Biosynthesis

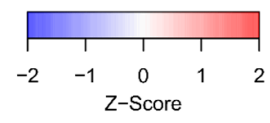

norspermidine biosynthesis

superpathway of $L$-aspartate and $L$-asparagine biosynthesis

Fermentation to Acetate

Formaldehyde Assimilation

Formaldehyde Oxidation

Glycerol Degradation
Pyrimidine Nucleotide Degradation

Pyrimidine Nucleotide Degradation
S-methyl-5-thio-alpha-D-ribose 1-phosphate degradation

superpathway of GICNAc, ManNAc and Neu5Ac degradation

superpathway of GICNAC, ManNAc and
superpathway of Neu5Ac degradation

polymyxin resistance

Anaerobic Respiration

TCA cycle VII (acetate-producers)

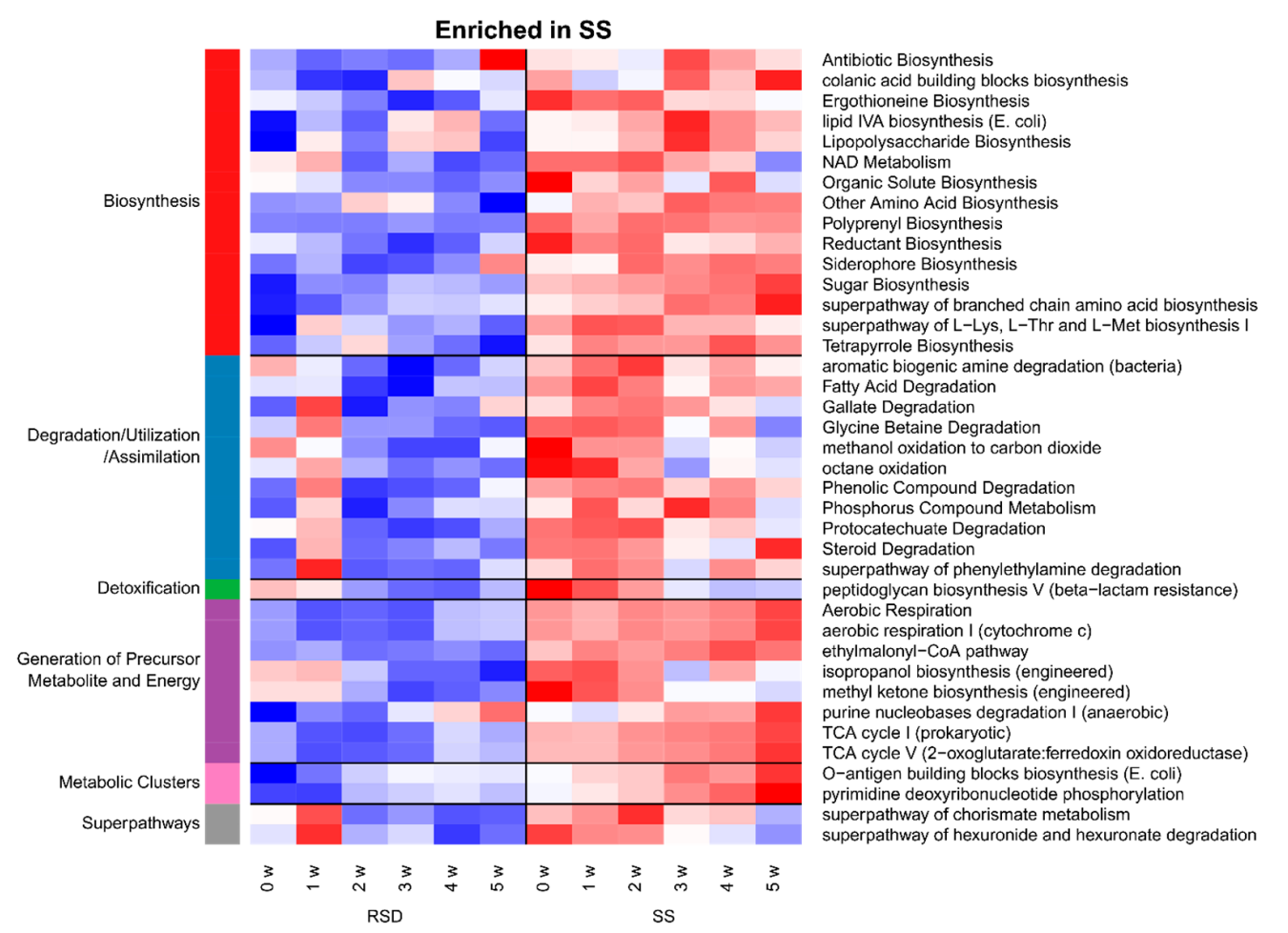

Figure 5. Relative abundances of the pathways predicted by PICRUSt2 in the soil bacterial metagenomes under reductive soil disinfestation (RSD) and soil solarization (SS). (A) Compositions of the predicted pathways (first level in MetaCyc hierarchy). The sum of relative abundance was more than $100 \%$ because some pathways were grouped into multiple parent classes. Most pathways in the "Superpathways" class overlapped with those in other classes; thus, such overlapped pathways in the "Superpathways" were filtered out. (B) Clustered heatmaps of the relative abundances of the predicted pathways (third level in MetaCyc hierarchy) were differentially abundant between RSD and SS (false discovery rate $<0.01$ ). The heatmap color indicates the z-score normalized relative abundances. Blue denotes -2 , whereas red denotes 2 . The left-side color indicates the parent class at the first level in the MetaCyc hierarchy. GlcNAc, N-acetylglucosamine; ManNAc, $\mathrm{N}$-acetylmannosamine; Neu5Ac, N-acetylneuraminate; $0-5 \mathrm{w}$, treatment period for 0 to 5 weeks. 


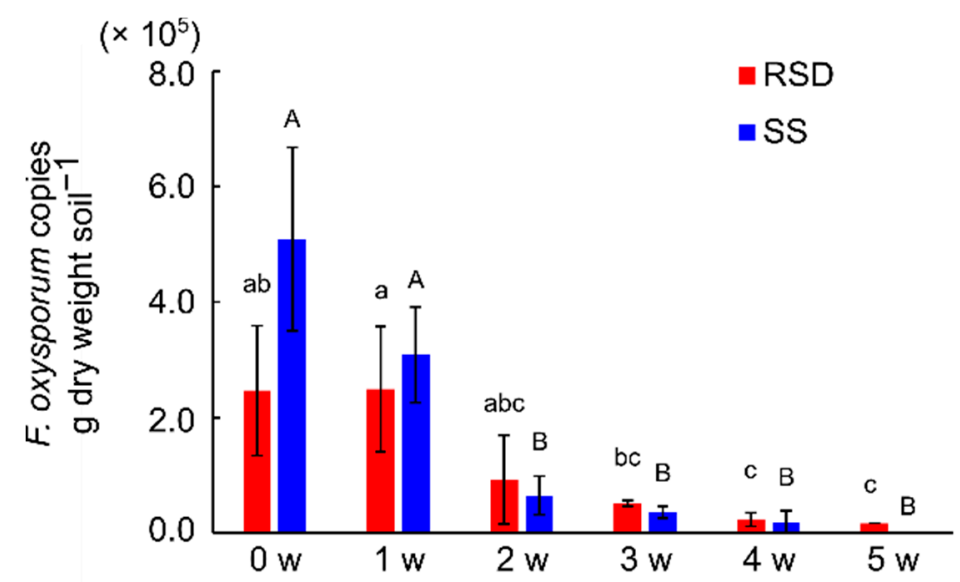

Figure 6. Populations of Fusarium oxysporum in the soil samples under reductive soil disinfestation (RSD) and soil solarization (SS). Red denotes RSD, whereas blue denotes SS. Values are the average, and error bars indicate standard deviation $(n=3)$. Different letters (a-c for RSD; A and B for SS) represent significant differences $(p<0.05)$ according to Tukey's test. $0-5 \mathrm{w}$, treatment period for 0 to 5 weeks.

\subsection{Effects of Soil Disinfestation on Soil Bacterial Communities and Tomato Growth during Cultivation}

It is unclear how long the effects of disinfestations last. To analyze whether the difference of bacterial communities between RSD and SS was maintained during the cherry tomato cultivation period, bacterial communities in soils sampled during the tomato cultivation period after these treatments were analyzed. WUF- and UUF-PCoA showed a clear distinction of the bacterial communities between RSD and SS (PERMANOVA, $p=0.019$ for WUF and $p=0.003$ for UUF; Figure 7). In contrast, the bacterial communities of both soils were not altered between 14 and 24 weeks later (PERMANOVA, $p=0.058$ for WUF and $p=0.237$ for UUF; Figure 7). These data indicated that the effects of RSD and SS continue even after 6 months.
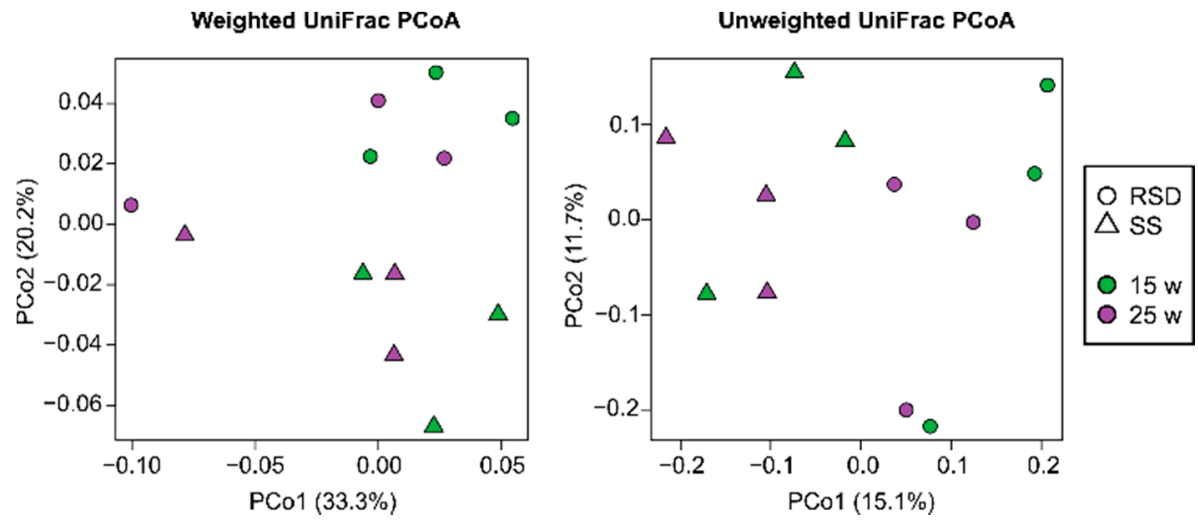

Figure 7. Weighted and Unweighted UniFrac-based principal coordinate analysis (PCoA) of the soil bacterial communities during the tomato cultivation period after $(\bigcirc)$ reductive soil disinfestation $(\mathrm{RSD})$ and $(\triangle)$ soil solarization (SS). Green and purple denote 15 and $25 \mathrm{w}$ : treatment period for 15 and 25 weeks.

Differences in bacterial communities between RSD and SS during the tomato cultivation period were confirmed. The effects of RSD and SS on the growth of cherry tomatoes during cultivation were also investigated. The length and perimeter of the main stem and length of internode on October 30 and the length of the main stem on November 27 were significantly different between RSD and SS (Table 1). Fruit yield showed a slight increase in SS $\left(5.64 \mathrm{~kg} \mathrm{~m}^{-2}\right)$ than in RSD $\left(5.23 \mathrm{~kg} \mathrm{~m}^{-2}\right)$ but not statistically tested due to singlicate. 
Table 1. Evaluation of the cultivated tomato plant growth after reductive soil disinfestation (RSD) and soil solarization (SS). Values are the average and standard deviation. Asterisks indicate statistically significant differences $(p<0.05)$ by Welch's $t$-test.

\begin{tabular}{cccccc}
\hline & & Main Stem $\mathbf{( c m )}$ & Internode $\mathbf{( c m )}$ & Leaf Area $\left(\mathbf{c m}^{\mathbf{2}}\right)$ & $\begin{array}{c}\text { Perimeter of } \\
\text { Stem }\end{array}$ \\
& & & & & \\
\hline \multirow{2}{*}{ October 16 } & RSD & $94.4 \pm 7.42$ & $24.7 \pm 1.89$ & $1.41 \times 10^{3} \pm 12.7$ & $3.3 \pm 0.053$ \\
& SS & $95.4 \pm 4.21$ & $24.1 \pm 1.10$ & $1.45 \times 10^{3} \pm 229$ & $3.4 \pm 0.081$ \\
\hline \multirow{2}{*}{ October 30 } & RSD & $151 \pm 7.18^{*}$ & $26.7 \pm 0.700^{*}$ & $1.90 \times 10^{3} \pm 41.8$ & $2.9 \pm 0.11$ \\
& SS & $139 \pm 9.64$ & $22.7 \pm 1.94$ & $1.79 \times 10^{3} \pm 313$ & $3.3 \pm 0.22 *$ \\
\hline \multirow{2}{*}{ November 13 } & RSD & $188 \pm 7.51$ & $18.8 \pm 2.79$ & $1.99 \times 10^{3} \pm 89.2$ & $3.8 \pm 0.061$ \\
& SS & $178 \pm 14.7$ & $19.5 \pm 3.31$ & $2.04 \times 10^{3} \pm 431$ & $4.0 \pm 0.42$ \\
\hline \multirow{2}{*}{ November 27 } & RSD & $226 \pm 2.60 *$ & $18.0 \pm 1.37$ & $1.63 \times 10^{3} \pm 56.0$ & $3.1 \pm 0.14$ \\
& SS & $209 \pm 20.8$ & $15.6 \pm 0.133$ & $1.80 \times 10^{3} \pm 497$ & $3.2 \pm 0.16$ \\
\hline
\end{tabular}

\section{Discussion}

To improve the profitability of organic farming, it is required to effectively control pathogens without using pesticides to grow plants healthily. Fusarium wilt is a major soil-borne tomato disease caused by FOL [52] and is difficult to prevent without pesticides. Both RSD and SS strongly suppressed the abundance of F. oxysporum. The suppressive effect by RSD was previously reported for several pathogens, including Agrobacterium tumefaciens, F. oxysporum, Ralstonia solanacearum, Rhizoctonia solani, Pythium spp., and Verticillium dahliae [53-58]. Pathogen suppression mediated by RSD is supposed to involve various chemical and biological mechanisms in a complicated manner [18,19]. The decrease in RP coincided with pathogen suppression [15], but the reductive condition alone was not lethal for F. oxysporum [18]. The results of the study suggested that even a moderately reduced condition is enough to suppress F. oxysporum and that the sequential chemical and biological modulations are essential. Another possible mechanism for pathogen control is the accumulation of toxic organic acids mediated by the anaerobic decomposition of organic substrates added at the start of disinfestation, accompanied by the $\mathrm{pH}$ decrease during RSD [59]. However, this study, including some previous works, indicated $\mathrm{pH}$ increase and pathogen suppression during RSD [60-62]. Nevertheless, the fluctuation of $\mathrm{pH}$ during RSD had different results depending on added organic substrates and initial $\mathrm{pH}$ at the start and the geographic locations, although the treatments showed pathogen suppression $[63,64]$. Thus, it remains unclear why the $\mathrm{pH}$ fluctuations during RSD differ among several studies and which pathogens are suppressed by organic acids. However, under the conditions set in this study, the observed suppression of F. oxysporum would be caused by factors other than organic acid generation with $\mathrm{pH}$ decrease.

The quantity, diversity, and community of soil-borne microbes are important indicators of soil quality and play key roles in plant growth and defense [24,65]. RSD treatment formed different bacterial and fungal communities from untreated soil by culture-dependent and culture-independent investigation [66]. At the phylum level of bacteria, members of Firmicutes (from both classes Clostridia and Bacilli) increased in the RSD-treated soil [25-27,67]. Because RSD makes soil reducing/anaerobic, it is reasonable to increase anaerobic microbes, such as Clostridia. In accordance with these findings, the relative abundance of class Clostridia tended to be inversely proportional to soil RP (Supplemental Figure S2B). Regarding the involvement of microbes in pathogen suppression during RSD treatment, specific strains of Clostridia and Bacilli from treated soils could have a disease control effect [30,32]. The families Ruminococcaceae, Lachnospiraceae, and Clostridiaceae belonging to Clostridia increased during RSD and produced toxic compounds against plant pathogens [68-70]. Time-series analysis of soil microbiome and metabolome during RSD demonstrated that composition of Firmicutes abundance continuously changes throughout the treatment period and that population dynamics of Clostridium spp. were correlated with temporal changes in abundances of organic acids, $p$-cresol, and methyl sulfides with antimicrobial activities [71]. These previous studies argue that Clostridia is responsible for 
suppressing pathogens. In this study, the suppression effects of $F$. oxysporum between RSD and SS treatments were similar, although Clostridia was not increased in SS as much as RSD (Supplemental Figure S2B), suggesting that microbes other than Clostridia may also be involved in the suppression. Indeed, the relative abundances of some groups belonging to the bacterial order Sphingobacteriales and fungal order Sordariales also increased by RSD, which were negatively correlated with disease incidence [60]. In addition to the pathogenic control effect, the abundances of the nitrogenase and ammonia monooxygenase genes related to nitrification increased in RSD-treated soil [68,72], suggesting the improvement of nutritional availability by RSD. Recently, SS was reported to induce organic nitrogen to increase plant growth [34]. The comparison between RSD and SS revealed that SS might be involved in siderophore production. This result gave a possibility of plant growth promotion by SS, although there was no significant difference in the effects of RSD and SS on cherry tomato plant growth. Furthermore, the legacy effect on the bacterial community was confirmed 3 months after treatment [73], in accordance with the observation of distinct bacterial communities between RSD and SS even during the tomato cultivation period. Thus, this study suggests that the effects of soil disinfestation on soil microbiota last during the cultivation period in organic farming.

Supplementary Materials: The following are available online at https:/ / www.mdpi.com/article/ 10.3390/agronomy11071375/s1, Figure S1: Air temperature observed outside the green house, Figure S2: Relative abundances of bacterial taxa in the soil samples under reductive soil disinfestation (RSD) and soil solarization (SS), Figure S3: Principal component analysis (PCA) of the pathway composition (eighth level in MetaCyc hierarchy) predicted by PICRUSt2 in the soil bacterial metagenomes under $(\bigcirc)$ reductive soil disinfestation (RSD) and $(\triangle)$ soil solarization (SS), Table S1: MetaCyc_pathway_hierarchy_(version 23.5), Table S2. Relative abundances of bacterial classes (mean relative abundance $>0.1 \%$ ) in the soil samples under reductive soil disinfestation (RSD) and soil solarization (SS), Table S3. Relative abundances of the predicted pathways in the soil samples under reductive soil disinfestation (RSD) and soil solarization (SS).

Author Contributions: Conceptualization, M.N., K.I., H.W., and A.S.; methodology, M.N., K.I., H.W., and A.S.; software, S.Y. and Y.A.; validation, M.N., K.I., and H.W.; formal analysis, M.N., S.Y., and Y.A.; investigation, M.N., K.I., and H.W.; resources, K.I. and H.W.; data curation, M.N., S.Y., and Y.A.; writing—original draft preparation, M.N., K.I., and S.Y.; writing—review and editing, K.Y., H.W., and A.S.; visualization, M.N. and S.Y.; supervision, K.Y. and A.S.; project administration, H.W. and A.S.; funding acquisition, Y.A., H.W., and A.S. All authors have read and agreed to the published version of the manuscript.

Funding: This research was funded in part by grants from the Core Research for Evolutional Science and Technology, Japan Science and Technology Agency (JPMJCR17O2 to Y.A. and A.S.), the Research Institute for Sustainable Humanosphere (Mission 1), and the Research Unit for Development of Global Sustainability, Kyoto University. H.W. and K.I. were partly supported by Commercialization Promotion Course II of Kigyonomori from KYOTO Industrial Support Organization 21.

Institutional Review Board Statement: Not applicable.

Informed Consent Statement: Not applicable.

Data Availability Statement: All the data is available in the paper.

Acknowledgments: The authors thank Keiko Kanai, Miwako Toyofuku and Hinako Matsuda for technical assistance.

Conflicts of Interest: The authors declare no conflict of interest.

\section{References}

1. Tilman, D.; Cassman, K.G.; Matson, P.A.; Naylor, R.; Polasky, S. Agricultural sustainability and intensive production practices. Nature 2002, 418, 671-677. [CrossRef]

2. Barnard, E.L.; Gilly, S.; Ash, E. An evaluation of dazomet and metam-sodium soil fumigants for control of Macrophomina phaseolina in a Florida forest nursery. Tree Plant. Notes 1994, 45, 91-95. 
3. Carey, W.A. Fumigation with chloropicrin, metham sodium, and EPTC as replacements for methyl bromide in southern pine nurseries. South. J. Appl. For. 2000, 24, 135-139. [CrossRef]

4. Hutchinson, C.M.; McGiffen, M.E.; Sims, J.J.; Becker, J.O. Fumigant combinations for Cyperus esculentum L control. Pest. Manag. Sci. 2004, 60, 369-374. [CrossRef] [PubMed]

5. Foley, J.A.; Ramankutty, N.; Brauman, K.A.; Cassidy, E.S.; Gerber, J.S.; Johnston, M.; Mueller, N.D.; O'Connell, C.; Ray, D.K.; West, P.C.; et al. Solutions for a cultivated planet. Nature 2011, 478, 337-342. [CrossRef] [PubMed]

6. Tuomisto, H.L.; Hodge, I.D.; Riordan, P.; Macdonald, D.W. Does organic farming reduce environmental impacts?-A metaanalysis of European research. J. Environ. Manag. 2012, 112, 309-320. [CrossRef]

7. Cavigelli, M.A.; Mirsky, S.B.; Teasdale, J.R.; Spargo, J.T.; Doran, J. Organic grain cropping systems to enhance ecosystem services. Renew. Agric. Food Syst. 2013, 28, 145-159. [CrossRef]

8. Seufert, V.; Ramankutty, N.; Foley, J.A. Comparing the yields of organic and conventional agriculture. Nature 2012, 485, $229-232$. [CrossRef]

9. Muller, A.; Schader, C.; Scialabba, N.E.-H.; Bruggemann, J.; Isensee, A.; Erb, K.-H.; Smith, P.; Klocke, P.; Leiber, F.; Stolze, M.; et al. Strategies for feeding the world more sustainably with organic agriculture. Nat. Commun. 2017, 8, 1-13. [CrossRef]

10. Erb, K.-H.; Lauk, C.; Kastner, T.; Mayer, A.; Theurl, M.C.; Haberl, H. Exploring the biophysical option space for feeding the world without deforestation. Nat. Commun. 2016, 7, 1-9. [CrossRef] [PubMed]

11. Barbieri, P.; Pellerin, S.; Seufert, V.; Smith, L.; Ramankutty, N.; Nesme, T. Global option space for organic agriculture is delimited by nitrogen availability. Nat. Food 2021, 2, 363-372. [CrossRef]

12. van Bruggen, A.H.C.; Finckh, M.R. Plant diseases and management approaches in organic farming systems. Annu. Rev. Phytopathol. 2016, 54, 25-54. [CrossRef] [PubMed]

13. Willer, H.; Lernoud, J. The World of Organic Agriculture. Statistics and Emerging Trends 2019; Research Institute of Organic Agriculture (FiBL): Frick, Switzerland; IFOAM-Organics International: Bonn, Germany, 2019.

14. Katan, J. Diseases caused by soilborne pathogens: Biology, management and challenges. J. Plant. Pathol. $2017,99,305-315$.

15. Blok, W.J.; Lamers, J.G.; Termorshuizen, A.J.; Bollen, G.J. Control of soilborne plant pathogens by incorporating fresh organic amendments followed by tarping. Phytopathology 2000, 90, 253-259. [CrossRef]

16. Shinmura, A. Causal agent and control of root rot of welsh onion. In Proceedings of the PSJ Soil-Borne Disease Workshop Report; 2000; pp. 133-143. Available online: https:/ / ci.nii.ac.jp/naid/10029720077/ (accessed on 5 July 2021).

17. Shrestha, U.; Auge, R.M.; Butler, D.M. A meta-analysis of the impact of anaerobic soil disinfestation on pest suppression and yield of horticultural crops. Front. Plant. Sci. 2016, 7, 1254. [CrossRef]

18. Momma, N.; Kobara, Y.; Uematsu, S.; Kita, N.; Shinmura, A. Development of biological soil disinfestations in Japan. Appl. Microbiol. Biotechnol. 2013, 97, 3801-3809. [CrossRef]

19. Ueki, A.; Kaku, N.; Ueki, K. Role of anaerobic bacteria in biological soil disinfestation for elimination of soil-borne plant pathogens in agriculture. Appl. Microbiol. Biotechnol. 2018, 102, 6309-6318. [CrossRef] [PubMed]

20. Momma, N.; Momma, M.; Kobara, Y. Biological soil disinfestation using ethanol: Effect on Fusarium oxysporum f. sp lycopersici and soil microorganisms. J. Gen. Plant. Pathol. 2010, 76, 336-344. [CrossRef]

21. Francioli, D.; Schulz, E.; Lentendu, G.; Wubet, T.; Buscot, F.; Reitz, T. Mineral vs. organic amendments: Microbial community structure, activity and abundance of agriculturally relevant microbes are driven by long-term fertilization strategies. Front. Microbiol. 2016, 7, 1446. [CrossRef]

22. Li, F.; Chen, L.; Zhang, J.B.; Yin, J.; Huang, S.M. Bacterial community structure after long-term organic and inorganic fertilization reveals important associations between soil nutrients and specific taxa involved in nutrient transformations. Front. Microbiol. 2017, 8. [CrossRef] [PubMed]

23. Lori, M.; Symnaczik, S.; Mader, P.; De Deyn, G.; Gattinger, A. Organic farming enhances soil microbial abundance and activity-A meta-analysis and meta-regression. PLoS ONE 2017, 12, e0180442. [CrossRef] [PubMed]

24. Berendsen, R.L.; Pieterse, C.M.J.; Bakker, P. The rhizosphere microbiome and plant health. Trends Plant. Sci. 2012, 17, 478-486. [CrossRef] [PubMed]

25. Mowlick, S.; Takehara, T.; Kaku, N.; Ueki, K.; Ueki, A. Proliferation of diversified clostridial species during biological soil disinfestation incorporated with plant biomass under various conditions. Appl. Microbiol. Biotechnol. 2013, 97, 8365-8379. [CrossRef] [PubMed]

26. Mowlick, S.; Yasukawa, H.; Inoue, T.; Takehara, T.; Kaku, N.; Ueki, K.; Ueki, A. Suppression of spinach wilt disease by biological soil disinfestation incorporated with Brassica juncea plants in association with changes in soil bacterial communities. Crop. Prot. 2013, 54, 185-193. [CrossRef]

27. Mowlick, S.; Inoue, T.; Takehara, T.; Tonouchi, A.; Kaku, N.; Ueki, K.; Ueki, A. Usefulness of Japanese-radish residue in biological soil disinfestation to suppress spinach wilt disease accompanying with proliferation of soil bacteria in the Firmicutes. Crop. Prot. 2014, 61, 64-73. [CrossRef]

28. Rosskopf, E.N.; Burelle, N.; Hong, J.; Butler, D.M.; Noling, J.W.; He, Z.; Booker, B.; Sances, F. Comparison of anaerobic soil disinfestation and drip-applied organic acids for raised-bed specialty crop production in Florida. In Proceedings of the VIII International Symposium on Chemical and Non-Chemical Soil and Substrate Disinfestation, Torino, Italy, 13-17 July 2014; pp. 221-228. 
29. Strauss, S.L.; Kluepfel, D.A. Anaerobic soil disinfestation: A chemical-independent approach to pre-plant control of plant pathogens. J. Integr. Agric. 2015, 14, 2309-2318. [CrossRef]

30. Ueki, A.; Takehara, T.; Ishioka, G.; Kaku, N.; Ueki, K. Degradation of the fungal cell wall by clostridial strains isolated from soil subjected to biological soil disinfestation and biocontrol of Fusarium wilt disease of spinach. Appl. Microbiol. Biotechnol. 2017, 101, 8267-8277. [CrossRef]

31. Ueki, A.; Takehara, T.; Ishioka, G.; Kaku, N.; Ueki, K. Production of beta-1,3-glucanase and chitosanase from clostridial strains isolated from the soil subjected to biological disinfestation. AMB Express 2019, 9, 1-14. [CrossRef]

32. Lee, C.G.; Kunitomo, E.; Iida, T.; Nakaho, K.; Ohkuma, M. Soil prokaryotes are associated with decreasing Fusarium oxysporum density during anaerobic soil disinfestation in the tomato field. Appl. Soil Ecol. 2020, 155, 103632. [CrossRef]

33. Katan, J. Solar Heating (Solarization) of Soil for Control of Soilborne Pests. Annu. Rev. Phytopathol. 1981, 19, 211-236. [CrossRef]

34. Ichihashi, Y.; Date, Y.; Shino, A.; Shimizu, T.; Shibata, A.; Kumaishi, K.; Funahashi, F.; Wakayama, K.; Yamazaki, K.; Umezawa, A.; et al. Multi-omics analysis on an agroecosystem reveals the significant role of organic nitrogen to increase agricultural crop yield. Proc. Natl. Acad. Sci. USA 2020, 117, 14552-14560. [CrossRef] [PubMed]

35. Haas, D.; Defago, G. Biological control of soil-borne pathogens by fluorescent pseudomonads. Nat. Rev. Microbiol. 2005, 3 , 307-319. [CrossRef] [PubMed]

36. Hoitink, H.A.J.; Boehm, M.J. Biocontrol within the context of soil microbial communities: A substrate-dependent phenomenon. Annu. Rev. Phytopathol. 1999, 37, 427-446. [CrossRef] [PubMed]

37. Weller, D.M.; Raaijmakers, J.M.; Gardener, B.B.M.; Thomashow, L.S. Microbial populations responsible for specific soil suppressiveness to plant pathogens. Annu. Rev. Phytopathol. 2002, 40, 309-348. [CrossRef] [PubMed]

38. Bolyen, E.; Rideout, J.R.; Dillon, M.R.; Bokulich, N.; Abnet, C.C.; Al-Ghalith, G.A.; Alexander, H.; Alm, E.J.; Arumugam, M.; Asnicar, F.; et al. Reproducible, interactive, scalable and extensible microbiome data science using QIIME 2. Nat. Biotechnol. 2019, 37, 852-857. [CrossRef]

39. Callahan, B.J.; McMurdie, P.J.; Rosen, M.J.; Han, A.W.; Johnson, A.J.A.; Holmes, S.P. DADA2: High-resolution sample inference from Illumina amplicon data. Nat. Methods 2016, 13, 581-583. [CrossRef]

40. Bokulich, N.A.; Kaehler, B.D.; Rideout, J.R.; Dillon, M.; Bolyen, E.; Knight, R.; Huttley, G.A.; Caporaso, J.G. Optimizing taxonomic classification of marker-gene amplicon sequences with QIIME 2's q2-feature-classifier plugin. Microbiome 2018, 6, 17. [CrossRef]

41. Quast, C.; Pruesse, E.; Yilmaz, P.; Gerken, J.; Schweer, T.; Yarza, P.; Peplies, J.; Glockner, F.O. The SILVA ribosomal RNA gene database project: Improved data processing and web-based tools. Nucleic Acids Res. 2013, 41, D590-D596. [CrossRef]

42. Katoh, K.; Standley, D.M. MAFFT Multiple sequence alignment software version 7: Improvements in performance and usability. Mol. Biol. Evol. 2013, 30, 772-780. [CrossRef]

43. Price, M.N.; Dehal, P.S.; Arkin, A.P. FastTree 2-approximately maximum-likelihood trees for large alignments. PLoS ONE 2010, 5, 10. [CrossRef]

44. Douglas, G.M.; Maffei, V.J.; Zaneveld, J.R.; Yurgel, S.N.; Brown, J.R.; Taylor, C.M.; Huttenhower, C.; Langille, M.G.I. PICRUSt2 for prediction of metagenome functions. Nat. Biotechnol. 2020, 38, 685-688. [CrossRef] [PubMed]

45. Caspi, R.; Billington, R.; Keseler, I.M.; Kothari, A.; Krummenacker, M.; Midford, P.E.; Ong, W.K.; Paley, S.; Subhraveti, P.; Karp, P.D. The MetaCyc database of metabolic pathways and enzymes-A 2019 update. Nucleic Acids Res. 2020, 48, D445-D453. [CrossRef] [PubMed]

46. Mule, G.; Susca, A.; Stea, G.; Moretti, A. Specific detection of the toxigenic species Fusarium proliferatum and F. oxysporum from asparagus plants using primers based on calmodulin gene sequences. Fems Microbiol. Lett. 2004, 230, 235-240. [CrossRef]

47. Oksanen, J.; Blanchet, F.; Friendly, M.; Kindt, R.; Legendre, P.; McGlinn, D.; Minchin, P.; O’Hara, R.; Simpson, G.; Solymos, P.; et al. vegan: Community Ecology Package. Available online: https:/ /CRAN.R-project.org/package=vegan (accessed on 5 July 2021).

48. Fernandes, A.; Macklaim, J.; Linn, T.; Reid, G.; Gloor, G. ANOVA-like differential gene expression analysis of single-organism and meta-RNA-seq. PLoS ONE 2013, 8, e67019.

49. Fernandes, A.D.; Reid, J.N.; Macklaim, J.M.; McMurrough, T.A.; Edgell, D.R.; Gloor, G.B. Unifying the analysis of high-throughput sequencing datasets: Characterizing RNA-seq, 16S rRNA gene sequencing and selective growth experiments by compositional data analysis. Microbiome 2014, 2, 1-13. [CrossRef]

50. Reddy, K.R.; DeLaune, R.D. Biogeochemistry of Wetlands: Science and Applications; CRC Press: Boca Raton, FL, USA, 2008.

51. Langille, M.G.; Zaneveld, J.; Caporaso, J.G.; McDonald, D.; Knights, D.; Reyes, J.A.; Clemente, J.C.; Burkepile, D.E.; Thurber, R.L.V.; Knight, R. Predictive functional profiling of microbial communities using $16 \mathrm{~S}$ rRNA marker gene sequences. Nat. Biotechnol. 2013, 31, 814-821. [CrossRef]

52. Larkin, R.P.; Fravel, D.R. Efficacy of various fungal and bacterial biocontrol organisms for control of Fusarium wilt of tomato. Plant. Dis. 1998, 82, 1022-1028. [CrossRef]

53. Browne, G.; Ott, N.; Poret-Peterson, A.; Gouran, H.; Lampinen, B. Efficacy of anaerobic soil disinfestation for control of prunus replant disease. Plant. Dis. 2018, 102, 209-219. [CrossRef] [PubMed]

54. Hewavitharana, S.S.; Ruddell, D.; Mazzola, M. Carbon source-dependent antifungal and nematicidal volatiles derived during anaerobic soil disinfestation. Eur. J. Plant. Pathol. 2014, 140, 39-52. [CrossRef]

55. Messiha, N.A.S.; van Diepeningen, A.D.; Wenneker, M.; van Beuningen, A.R.; Janse, J.D.; Coenen, T.G.C.; Termorshuizen, A.J.; van Bruggen, A.H.C.; Blok, W.J. Biological Soil Disinfestation (BSD), a new control method for potato brown rot, caused by Ralstonia solanacearum race 3 biovar 2. Eur. J. Plant. Pathol. 2007, 117, 403-415. [CrossRef] 
56. Momma, N.; Yamamoto, K.; Simandi, P.; Shishido, M. Role of organic acids in the mechanisms of biological soil disinfestation (BSD). J. Gen. Plant. Pathol. 2006, 72, 247-252. [CrossRef]

57. Shennan, C.; Muramoto, J.; Koike, S.; Baird, G.; Fennimore, S.; Samtani, J.; Bolda, M.; Dara, S.; Daugovish, O.; Lazarovits, G.; et al. Anaerobic soil disinfestation is an alternative to soil fumigation for control of some soilborne pathogens in strawberry production. Plant. Pathol. 2018, 67, 51-66. [CrossRef]

58. Strauss, S.L.; Greenhut, R.F.; McClean, A.E.; Kluepfel, D.A. Effect of anaerobic soil disinfestation on the bacterial community and key soilborne phytopathogenic agents under walnut tree-crop nursery conditions. Plant. Soil 2017, 415, 493-506. [CrossRef]

59. Huang, X.Q.; Liu, L.L.; Wen, T.; Zhu, R.; Zhang, J.B.; Cai, Z.C. Illumina MiSeq investigations on the changes of microbial community in the Fusarium oxysporum f.sp cubense infected soil during and after reductive soil disinfestation. Microbiol. Res. 2015, 181, 33-42. [CrossRef]

60. Liu, L.L.; Huang, X.Q.; Zhao, J.; Zhang, J.B.; Cai, Z.C. Characterizing the key agents in a disease-suppressed soil managed by reductive soil disinfestation. Appl. Environ. Microbiol. 2019, 85, e02992-18. [CrossRef] [PubMed]

61. Meng, T.Z.; Ren, G.D.; Wang, G.F.; Ma, Y. Impacts on soil microbial characteristics and their restorability with different soil disinfestation approaches in intensively cropped greenhouse soils. Appl. Microbiol. Biotechnol. 2019, 103, 6369-6383. [CrossRef] [PubMed]

62. Tan, X.Y.; Liao, H.K.; Shu, L.Z.; Yao, H.Y. Effect of different substrates on soil microbial community structure and the mechanisms of reductive soil disinfestation. Front. Microbiol. 2019, 10, 2851. [CrossRef]

63. Testen, A.L.; Miller, S.A. Anaerobic Soil Disinfestation to Manage Soilborne Diseases in Muck Soil Vegetable Production Systems. Plant. Disease 2019, 103, 1757-1762. [CrossRef] [PubMed]

64. Zhao, J.; Zhou, X.; Jiang, A.Q.; Fan, J.Z.; Lan, T.; Zhang, J.B.; Cai, Z.C. Distinct impacts of reductive soil disinfestation and chemical soil disinfestation on soil fungal communities and memberships. Appl. Microbiol. Biotechnol. 2018, 102, 7623-7634. [CrossRef]

65. Janvier, C.; Villeneuve, F.; Alabouvette, C.; Edel-Hermann, V.; Mateille, T.; Steinberg, C. Soil health through soil disease suppression: Which strategy from descriptors to indicators? Soil Biol. Biochem. 2007, 39, 1-23. [CrossRef]

66. Zhou, X.; Li, C.Y.; Liu, L.L.; Zhao, J.; Zhang, J.B.; Cai, Z.C.; Huang, X.Q. Control of Fusarium wilt of lisianthus by reassembling the microbial community in infested soil through reductive soil disinfestation. Microbiol. Res. 2019, 220, 1-11. [CrossRef]

67. Mowlick, S.; Hirota, K.; Takehara, T.; Kaku, N.; Ueki, K.; Ueki, A. Development of anaerobic bacterial community consisted of diverse clostridial species during biological soil disinfestation amended with plant biomass. Soil Sci. Plant. Nutr. 2012, 58, 273-287. [CrossRef]

68. Huang, X.Q.; Liu, L.L.; Wen, T.; Zhang, J.B.; Wang, F.H.; Cai, Z.C. Changes in the soil microbial community after reductive soil disinfestation and cucumber seedling cultivation. Appl. Microbiol. Biotechnol. 2016, 100, 5581-5593. [CrossRef] [PubMed]

69. Huang, X.Q.; Liu, L.L.; Zhao, J.; Zhang, J.B.; Cai, Z.C. The families Ruminococcaceae, Lachnospiraceae, and Clostridiaceae are the dominant bacterial groups during reductive soil disinfestation with incorporated plant residues. Appl. Soil Ecol. 2019, 135, 65-72. [CrossRef]

70. Huang, X.Q.; Zhao, J.; Zhou, X.; Han, Y.S.; Zhang, J.B.; Cai, Z.C. How green alternatives to chemical pesticides are environmentally friendly and more efficient. Eur. J. Soil Sci. 2019, 70, 518-529. [CrossRef]

71. Hewavitharana, S.S.; Klarer, E.; Reed, A.J.; Leisso, R.; Poirier, B.; Honaas, L.; Rudell, D.R.; Mazzola, M. Temporal dynamics of the soil metabolome and microbiome during simulated anaerobic soil disinfestation. Front. Microbiol. 2019, 10. [CrossRef]

72. Poret-Peterson, A.T.; Sayed, N.; Glyzewski, N.; Forbes, H.; Gonzalez-Orta, E.T.; Kluepfel, D.A. Temporal responses of microbial communities to anaerobic soil disinfestation. Microb. Ecol. 2020, 80, 191-201. [CrossRef]

73. van Agtmaal, M.; van Os, G.J.; Hol, W.H.G.; Hundscheid, M.P.J.; Runia, W.T.; Hordijk, C.A.; de Boer, W. Legacy effects of anaerobic soil disinfestation on soil bacterial community composition and production of pathogen-suppressing volatiles. Front. Microbiol. 2015, 6, 701. [CrossRef] 